\title{
Normality unpacked: migration, ethnicity and Local Structure of Feeling among Polish migrant workers in Northern Ireland with a comparative perspective on Scotland.
}

\author{
Radoslaw Polkowski
}

Department of Human Resource Management, University of Strathclyde, Glasgow, UK

\author{
55 South Gyle Gardens
}

EH12 7SA Edinburgh

United Kingdom

Mobile phone: $+44(0) 7482752082$

e-mail: radek.polkowski@strath.ac.uk

Radosław Polkowski was a research fellow in the Marie-Skłodowska Curie 'Changing Employment' programme at the University of Strathclyde, a lecturer in Korean Studies at the University of Wroclaw, and is now a research fellow at the Academy of Korean Studies conducting a research on migration to South Korea. Besides his academic writing, he contributes with articles to Hankyoreh - one of South Korea's largest selling newspapers. Of additional special interest both within the academy and in the policy community is his media work which embraces both photographic exposure and video presentations. His photographic work has received two awards and he has completed a documentary film called 'Our Kingdom' about migrant workers in Northern Ireland.

This work was supported by the FP7-PEOPLE-2012-ITN project 'Changing Employment' ('The changing nature of employment in Europe in the context of challenges, threats and opportunities for employees and employers') under Grant no. 317321.

\section{Acknowledgements}

I am thankful to Prof. Paul Stewart for his continuous intellectual support and for serving as a source of inspiration during this research. I am especially grateful for his great openness to my ideas right from the beginning of this research project as it allowed me to develop a novel perspective on the study of migration and to take a unique path with which I could strongly identify. 


\title{
Normality unpacked: migration, ethnicity and Local Structure of Feeling among Polish migrant workers in Northern Ireland.
}

\author{
Previous literature on Polish migration to the UK identified a discourse of \\ normality as a grand narrative in migrants' justifications for living and working \\ abroad. The present article contributes to this literature by asking what happens \\ to this discourse in the circumstances of the UK, where it cannot be easily \\ sustained. To explore this issue, the case of Northern Ireland is chosen and it is \\ illustratively compared to that of Scotland. Using the concept of Structures of \\ Feeling to frame the analysis of semi-structured interviews with Polish migrant \\ workers, the study shows that, on the one hand, migration experience in Northern \\ Ireland seems to undermine the ideal of a normal life as well as the idealised \\ images of the UK that the discourse of normality conveys. However, it also \\ shows that this discourse remains an important feature of migrants' narratives. In \\ accounting for this inconsistency within interviews, the article proposes the \\ notion of 'normality through exclusion'. It also shows that, although not \\ straightforwardly different from the experience of migration to other parts of the \\ UK, the experience of migration to Northern Ireland is also characterised by \\ certain subtleties which are well accounted for by the concept of Structures of \\ Feeling.
}

Keywords: migration, Polish migrants in the UK, Structures of Feeling, normality, Northern Ireland.

\section{Introduction}

The enlargement of the European Union (EU) in 2004 spurred a significant increase in migration from Central and Eastern Europe (CEE) to some of the Western European countries, in particular the UK. Among these post-accession migrants the largest national group has consisted of workers from Poland. One of the most frequently recurring themes in the previous studies on Polish migrants in the UK has been the notion of normality as an aspiration that drives this migration (Gałasińska and Kozłowska 2009; Galasińska 2009; Rabikowska 2010; McGhee, Heath, and Trevena 2012; Drinkwater and Garapich 2015). Building on previous studies on post- 
communist societies (Kennedy 1994; Rausing 2002), this literature posits that one of the particular features of CEE societies is a sense of longing for a comfortable life that is free from material deprivation and allows an individual to afford desired consumer goods as well as to forge unproblematic identities. This type of lifestyle is subjectively associated with Western Europe and, in line with this, these studies show that, when justifying their decisions to live and work in Britain, Polish migrants portray themselves as deprived of normality in their country of origin. As explained by Drinkwater and Garapich $(2015,1925)$, the notion of normality in these accounts refers to 'a combination of factors making life easier than back home'.

The study by Gałasińska and Kozłowska (2009) has been the main point of reference in this sub-set of the literature on Polish migration to the UK. The notion of normality in the narratives of migrants interviewed in this study was constructed around expectations of employment standards that were linked to broader expectations related to life beyond work. Specifically, interviewees saw employment conditions in Poland as not normal because of the presumptively dishonest practices of employers and the role of informal social networks which made obtaining a desired job very difficult. In addition, wages from employment were perceived as insufficient for living a decent life. In contrast, migrants perceived the labour market in the UK as open (i.e. allowing relatively easy entry and career progress) and wages as modest but sufficient. Another aspect of the discourse of normality identified by Gałasińska and Kozłowska (2009) was the practice of juxtaposing the countries of departure and destination in a way that manifested the former as still in the process of becoming normal. In contrast, Britain was positively idealised as a prosperous, wealthy, and modern state where good employment standards prevailed, thus offering a comfortable, unproblematic life. This is consistent with the idealisation of the West as a Promised Land that has been 
prevalent in Polish cultural and public discourses, especially after 2004 when increased migration to the West ensued (Kazimierska, Piotrowski, and Waniek 2011, 144).

However, 'what is life in the UK from the Shetland Isles to Salford? Or shared between the mansions of Holland Park and the council estates of neighbouring Shephard's Bush?' (Anderson 2013, 116). In other words, just as migration discourses convey a certain idealised image of a state, referred to by Anderson (2013) as a Community of Value, the discourse of normality builds on an idealised and homogenised myth of Britain that overlooks class, ethnic, territorial, and various other inequalities that sometimes sit uneasily with the above-described image. Therefore, the present article poses a question: what happens to this idealising and homogenising discourse of normality in the circumstances of the UK, where it cannot be easily sustained?

To answer this question the article draws on data from 18 semi-structured interviews with Polish workers in Northern Ireland or, as preferred by Irish nationalists, 'the north of Ireland'. Here the notions of normality, modernity, unproblematic identities, and a comfortable, hassle-free life are most likely, at least in theory, to conflict with people's lives and identities that are to a large extent determined, shaped, or at least affected by an ethnic tribalism whose origins can be traced to pre-modern times. This problematic context that meets Polish migrants on arrival is discussed in the first section of the present article.

Following this, the second section unpacks the conceptual framework that allows us to make sense of migrants' experiences in this part of the UK. Specifically, it digs into a concept long-established in social theory, that of Structures of Feeling, which originates in the cultural and literary studies of Raymond Williams. Drawing on its original formulation as well as its subsequent applications outside cultural theory, 
especially in urban studies (Evans, Taylor and Fraser 1996) and the sociology of work (Strangleman 2012, 2015), the concept is reformulated in the present article in a way that better equips it to account for the dynamism involved in migration experience and, hence, also makes it more useful for future migration research. In particular, the concept of Structures of Feelings as it will be defined in this article draws attention to a tension between, on the one hand, public ideals, ethics, and norms, and, on the other hand, actual experiences of life.

This type of tension is then illustrated in subsequent empirical sections of the article which explicate how the discourse of normality - supposedly 'a new grand narrative - a blueprint for all stories' (Gałasińska and Kozłowska 2009, 95) - fails to match the experience of life in the sectarian labour market and communities of Northern Ireland. For illustrative purposes, a comparative data from 17 semi-structured interviews with Polish migrants in Scotland is also used. Insofar as the discourse of normality is driven by certain social norms, ethics, and public ideals in Poland about migration practices and life more broadly (Gałasińska and Kozłowska 2009), the tension conveyed in the empirical data from Northern Ireland can be accounted for through the concept of Structures of Feeling.

Moreover, the image of the receiving country which arises from Polish migrants' narratives appears to be quite different from the idealised view of the UK conveyed by discourses of normality. However, the last empirical section indicates that, despite this Local Structure of Feeling (Evans, Taylor, and Fraser 1996), the discourse of normality with its idealisation of the UK can be sustained in migrants' narratives. In trying to account for this apparent tension between the discourse of normality and experiences of life in the UK, particularly the experiences of ethno-sectarian divisions, the last section proposes the notion of 'normality through exclusion', arguing that 
migrants can benefit from being symbolically excluded from the two dominant sectarian communities because such exclusion allows them to carry on the normal lives they desire. At the same time, however, they risk being socially, economically and politically marginalised as a group in the long run.

Finally, the concluding section proposes that, while it is not straightforwardly different from the experience of migration to other parts of the UK, the experience of migration to Northern Ireland, as it is conveyed in the narratives of the 18 people interviewed in this study, is also characterised by certain subtleties which are well accounted for by the concept of Structures of Feeling. Considering the size of the sample, it is hard to draw definite and generalisable conclusions about how Polish migrants integrate into this part of the country. Instead, the hope is that the reformulation of the concept of Structures of Feeling offered in this article is a significant addition to Williams's work and that it will encourage scholars of migration to envision the possibility of researching migration, in particular the role of place in it, in different terms.

\section{Northern Ireland: sectarianism, neoliberalism and migration.}

Up to the 1990s, Northern Ireland had been a state within a state, built on sectarian, loyalist-Protestant supremacy that kept the nationalist Catholic population disproportionately impoverished by excluding or marginalising it in politics, public employment, and public housing. In 1968, this long-standing discrimination culminated in a civil rights demonstration in the city of Derry/Londonderry that was violently suppressed by the authorities. This event ushered in a three-decades-long period of civil insurgency known as the Troubles.

The violence of this period, with its social and economic consequences, can explain why there was no significant inward migration to Northern Ireland at that time 
and why, ethno-sectarian divisions apart, it remains a relatively ethnically homogeneous country. However, less than six years after the Troubles officially ended in 1998 with the Good Friday Agreement (GFA), Northern Ireland as part of the UK joined the EU's single market. Soon afterwards, it became a part of the UK that was characterised by one of the highest concentrations of CEE migrant workers (Department of Employment and Learning 2009). Among them, Polish workers have been the largest group.

Unlike the rest of the UK, which has received not insignificant numbers of postwar migrants from Poland, Northern Ireland was in a way a new territory for postaccession workers from this country. Moreover, the context of reception from the perspective of a Polish migrant is arguably more problematic in this part of the country than elsewhere. First of all, the nature of ongoing ethno-sectarian divisions creates a particularly difficult context for migrants who come from a predominantly Catholic country because they can be instrumentally categorised by the Protestants as part of the historically rival community (Rijswijk, Hopkins, and Johnston 2009). This situation becomes especially troubling in the context of 'an enduring sense of decline and ideological defeat' within the Protestant community (Murtagh and Shirlow 2006, 15).

This sense of decline is related to the GFA which loosened the grip of the loyalists on public resources and jobs. More specifically, the GFA was built on an intercommunity consensus between the two sides of the sectarian conflict and the political parties representing them that was facilitated by the governments of the UK and the Republic of Ireland. Thus, rather than challenging and trying to get rid of sectarianism, the GFA institutionalised it (Murtagh and Shirlow 2012; Kelly 2012; Garvey and Stewart 2015). For example, funding of community activities, cultural agencies, and education is organised along sectarian divisions and is 'tied to each bloc publicly articulating that it is delivering its constituents through the redistribution of 
state funds that upholds respective electorate's needs and cultural demands' (Murtagh and Shirlow 2012, 50). Such a setup encourages each ethno-sectarian community to see the other as a competitor for resources, in significant contrast to pre-GFA times when Protestants were protected from such competition by the sectarian state.

Furthermore, this competition takes place in the context of a shift from Keynesian to neoliberal policies. According to Kelly $(2012,3)$, neoliberalism was promoted by 'the architects of the peace process in Washington and London' and embraced by all sides of the northern establishment. It results in cuts in public resources and deteriorating standards of employment (Garvey and Stewart 2015). As resources (i.e. public sector jobs, good employment overall, housing, funding for communities, and other requisites) are squeezed out by policies of welfare retrenchment and austerity, politicians on the two sides of the sectarian divide may increasingly focus on scapegoating the other party and blaming them for the destitution of their working-class constituents. On top of this come migrants who throughout the UK are commonly seen as competitors for 'British jobs'. In Northern Ireland, a sense of threat from migration might be even greater because of this convergence of neoliberalism and sectarianism.

Moreover, despite the so-called peace process, Northern Ireland and especially Belfast remain characterised by highly observable forms of spatial division. Indeed, walls dividing communities have become longer and higher ever since the commencement of the peace process and they continue to divide people even after death, as exemplified by the underground wall in the Belfast City Cemetery (Murtagh and Shirlow 2006, 13). Furthermore, residents' travel patterns, use of public services, choice of workplaces, and even leisure patterns have been shown to be continually determined by fear of sectarian violence (Murtagh and Shirlow 2006). 
This is the context which predominantly Catholic Polish migrant workers enter on their arrival. If their migration is driven by a longing for normality, do they find it in a country where the place where one works, sleeps, seeks entertainment, studies or gets medical help is to a large extent determined not by rational considerations but, instead, by fear or hatred? Moreover, what happens to the notion of normal employment in a labour market underlined by ethno-sectarian segregation? Similarly, what happens to the fantasy of modern Britain in a place where public and economic life is shaped by pre-modern tribal allegiances? Every year people across Northern Ireland gather in socalled Orange Parades to express their sectarian loyalties by commemorating a battle that took place in 1690 . How compatible is this with the idea of modernity and normality? Before answering these questions, the next section unpacks the conceptual framework used to explore migrant workers' narratives.

\section{Unpacking the concept of Structures of Feeling.}

The concept of Structures of Feeling was first proposed by Williams in 'A preface to Film' in the 1950s. It then evolved over his entire career through 'The Long Revolution' in the 1960s and 'Marxism and Literature' in the 1970s, and was revisited in an interview for the New Left Review at the turn of the 1970s and 1980s. Overall, Williams (1961) explained his concept through its relation to public discourses: whereas the latter notion refers to public ideals, the former 'has to deal not only with the public ideals but with their omissions and consequences, as lived' (Williams 1961, 63). In other words, while discourses are about normative ideals, values, beliefs, or ethics of different social groups, organisations or cultures, Structures of Feeling are about the actual experience of these ideals, values, beliefs and ethics. This experience is shared by a group of people (e.g. class, generation) because, as put by Williams $(1961,48)$, it is 'a particular community of experience hardly needing expression, through which the 
characteristics of our way of life that an external analyst could describe are in some way passed, giving them a particular and characteristic colour'.

An example given by Williams can be helpful in coming to grips with this concept. In the 1840s, he argued, literary works in Britain drew upon a discourse conveying an ethic that success follows individual effort and hard work, that wealth is the mark of respect, and that thrift is an important virtue. However, he also noted that such:

confident assertions (...) had to contend, if only unconsciously, with a practical world in which things were not so simple. The confidence of this fiction is often only superficial. What comes through with great force is a pervasive atmosphere of instability and debt (...) debt and ruin haunt this apparently confident world. (Williams 1961, 82)

Williams developed his concept chiefly in relation to cultural and literary studies, but there have been attempts to extend it further. For example, Strangleman's (2015) use of the notion of 'industrial structure of feeling' accounted for feelings of nostalgia and interpretation of the new working environment by older workers at the now-closed Guinness Brewery at Royal Park in London. In one of his earlier studies he looked at similar interpretations and experiences among older male workers in the railway industry in the UK and indicated that it would be foolish to dismiss them as 'private troubles which statistics do not recognise' or 'as simple nostalgia', suggesting that these narratives can be understood as 'valuable organic critiques of industrial and social change emergent from work culture' (Strangleman 2012, 411-423). For him, workers' feelings and experiences signified a clash between an ethic which they had brought with them from the Fordist era and the experience of life in the post-Fordist workplace. This is an important contribution to the concept, especially for its potential to transfer it from cultural and literary studies to the field of migration studies. More 
particularly, just as the ethic adhered to by the older workers whom Strangleman studied came up against the new context of post-Fordist capitalism that confronted them, migrant workers may be carrying with them the ethic developed in their countries of origin (e.g. the ethic conveyed in the discourse of normality) and experiencing it in the new context of the country of destination.

This assertion becomes especially interesting in light of the formulation of the notion of Local Structure of Feeling by Evans, Taylor and Fraser (1996). These authors argue that:

each urban area, region, and locality involves a given inheritance of geographical form (morphology), climate, industrial base, labour market and labour history, patterns of in-migration and emigration, ethnic and cultural mix, conflicts and contests (...) that define it and endow it with which, as we suggested earlier, can perhaps be thought of as a 'local structure of feeling'. (Evans, Taylor and Fraser 1996, 32).

They define this concept as an identity of a place conveyed through the way different publics live and actively reinterpret it. They also see a Local Structure of Feeling as composed of a sense of a place, everyday practices and cultural assumptions, interpretations and meanings attached to a place, as well as local wisdom and folklore associated with it (Evans, Taylor and Fraser 1996). Like Strangleman's two studies, the conceptualisation proposed by Evans, Taylor and Fraser (1996) is an important development of the idea. The main reason for this is the refocusing of the emphasis onto a place, which makes it possible to bring the concept into the study of migration. More specifically, Williams defined Structures of Feeling as an area of tension between the ethic and the experience of this ethic that is particular to certain generations or social classes. But the study by Evans, Taylor and Fraser (1996) suggests that the concept is 
also useful in exploring how specific political, social and economic contexts are experienced and interpreted.

However, their focus on the identities of the two English cities (Sheffield and Manchester) conveys a somewhat static character of Structures of Feeling. Against this picture, it can be argued that when people move between countries and cities, as happens in the process of migration, places are reinterpreted more dynamically as a result of experiencing a new context in the migration destination and relating it back to experiences in the country of departure. Therefore, Structures of Feeling should be thought of not as a phenomenon with a fixed identity but, rather, as an ongoing process of experiencing and reinterpreting places of departure and destination. In addition, drawing on Williams's original formulation of the concept, this process is driven by the relationship between the ethic (e.g. an ethic that underlines the discourse of normality) and an actual experience of life that may not go hand-in-hand with this ethic.

Based on such a definition of the concept, some questions can be posed: what is the Local Structure of Feeling that migrant workers from Poland, driven by ideals of normality, develop in relation to a not-so-normal place such as Northern Ireland? To what extent is the discourse of normality compatible with this Local Structure of Feeling? If it is compatible at all, what is the mechanism that allows this? These questions are addressed in the empirical sections below. First, however, research methods will be introduced.

\section{Research methods}

The article is a part of a larger research project that also included Polish migrants in Edinburgh (Scotland) and Ukrainian migrants in Wroclaw (Poland). While illustrative comparisons are occasionally made with findings from the Scottish sample, the data discussed below are based primarily on semi-structured interviews with 18 respondents 
in Northern Ireland. On the one hand, the size of the sample means that the study does not represent the experience of all migrants in Northern Ireland. On the other hand, the diverse (in terms of socio-economic background) sample collected for this study gives an indication of what the Local Structure of Feeling is and how it relates to the discourses and ethics of normalcy identified in the previous literature on Polish migration to the UK. This sample was collected using purposive sampling in which the initial number of respondents were drafted from personal contacts and subsequent interviewees were accessed by the snowballing technique. Most of the interviewees were aged between the late twenties and mid-thirties, except for one person aged 52. All had lived in the UK for at least five years uninterruptedly prior to the first interview.

Moreover, all but three participants were interviewed twice, the first interviews being conducted in 2013 and the follow-up interviews the year after. Every interview was recorded, transcribed, and coded. To begin with, line-by-line coding was performed on each transcript. Following certain codes and deciding which of them were more relevant gradually led the analysis to another phase of coding in which the most significant and recurring codes were selected and grouped into categories (e.g. discourse of normality). Particularly important in this transition to the second, more abstract phase was theoretical sensitivity (Glaser 1978), which yielded the observation that what the data was showing had been described in previous literature as Structures of Feeling.

This concept should be seen as a sensitising concept (Blumer 1969), that is, one which makes us aware of certain processes and mechanisms that are irreducible to a set of testable variables. Williams developed this concept from the literary work he used as sources of data. Subsequently, Evans et al. (1996) and Strangleman (2012, 2015) refined it during the process of using it to understand their own data. The present thesis drew upon these studies but, following Blumer's (1969) argument that the meaning of 
concepts is to be developed or discovered in the course of research, specifically through the study of empirical data that uncovers their different elements and aspects, the concept of Structures of Feeling was further refined. In particular, it was conceptualised here as a process that, as the following empirical sections will show, appears to be highly relevant in migration studies.

\section{Uncertainty, insecurity and fear: Polish migrants arriving in sectarian workplaces and neighbourhoods.}

The first point of contact with the receiving country for a migrant worker and, therefore, arguably the place where migrants' first interpretations of a place of destination are forged, is a workplace. In Northern Ireland, workplaces were the points of contact with ethno-sectarian divisions, which can be illustrated by the following quote from a thirtyfive-year-old factory worker named Pawel: 'At our company, the majority - maybe $90 \%$ or $80 \%$ - are Protestants. The only Catholic people there are Polish workers'. Another noticeable feature of migrants' accounts of workplaces was a complete lack of reports of ethnic diversity. It is interesting to note that this stands in stark contrast to the content of narratives of migrants in Scotland who were interviewed for the research of which the present article is a part. This can be best illustrated by the quote from Kaja, who arrived to work in Belfast after living for some time in Edinburgh and was surprised by the small number of foreigners employed in her workplace:

Interviewer: What were your first impressions when you came here?

Kaja: The weather was awful. It was raining, all my shoes were wet. It was a big difference coming here. Besides this, there were not many foreigners at my work. Kaja, 28 years old, self-employed

Indeed, descriptions of diverse workplaces similar to the one below were a defining theme in the early experiences of migrants interviewed in Scotland: 
There was a very high circulation of people. There were students, Spanish or Italians. It was very mixed. So no one paid attention to your nationality. Our clients were also mostly foreigners, especially in the summer.

Ewa, 33 years old, waitress, Edinburgh

Moving on from the workplace, neighbourhoods and communities are arguably the second most important points where migrants' first interpretations of a place can be forged. The quote below is a continuation of Kaja's earlier remarks, but this time she talks about her impressions outside the workplace:

There are some things about the culture and history here that you can notice when you see the police station that is so fortified and all those walls, security fences and so on. So these are some kind of first feelings.

Kaja, 28 years old, self-employed

The quote above conveys some undefined feelings about the place that emerge from Kaja's encounter with traces of ethno-sectarian divisions (i.e. fortified police stations and security walls). Typically the narratives on neighbourhoods and communities were marked with a sense of uncertainty that can be best illustrated by the quote below:

You come to the new country, you don't know anyone, you don't know the situation, you don't know where you can go because there are divisions. You know that Catholic Irish don't go to Protestant streets. So you also don't know where you can go and where you cannot. There are streets where Poles are not welcome and it's better if they don't go there.

Roman, 35 years old, shop assistant

The narratives on Northern Ireland's topography were commonly covered with a veil of uncertainty, conveyed in what could be thought of as quasi-folkloric tales and local wisdom (Evans, Taylor and Fraser 1996). Examples are found in anecdotes passed 
on by word of mouth, which interviewees often recounted as if they were fascinating legends:

There was a period of time when ... cause I didn't witness it but I've heard ... there are two neighbourhoods and a football pitch in-between them. On the one side there are Catholics and on the other side Protestants. There was a situation that Protestants went on the football pitch with golf balls and played golf on Catholic houses. There is also one Protestant neighbourhood where a Catholic cannot enter. Same with a foreigner. It doesn't matter if he's black, Hindu, or Japanese. You can't enter if you're not a Protestant. Marek, 35 years old, factory worker

As is typical of legends, these anecdotes were steeped in mystery surrounding certain 'evil' places where one should not venture, as also seen in the quote above. Moreover, a vocabulary like that of fairy tales was sometimes used, as when Grzegorz talked about 'a magic line' dividing Belfast:

There's a magic red line going through the map of Belfast that no-one has ever drew but that all local people and letting agencies know about. Poles have no idea about it. It's a line which says where the foreigners can settle and where they by all means should not.

Grzegorz, 39 years old, professional services worker

These narratives are marked with a sense of fear which is explicitly invoked by the last words in the following quote:

On the week of 12th July, some shops are closed (...) They can be open but they may be sprayed with paint or have their windows broken. There's more police on streets in that week. There are vehicles on streets which look like tanks. Police walks around with weapons. It does look quite impressive, I must say, but also quite scary. Jagoda, 52 years old, farm worker 
As posited by Evans, Taylor and Fraser (1996), local wisdom and folklore about a place are part of its identity and, hence, part of its Local Structure of Feeling. In Northern Ireland we can see that the Local Structure of Feeling is marked with a sense of uncertainty, insecurity and fear. In turn, these feelings can influence how people live and act. Specifically, the examples above indicate that migrants may constrain their use of public spaces. For instance, they may think twice about renting a flat in or even walking through certain areas.

In this way, their experience of ethno-sectarian divisions in Northern Ireland has arguably little to do with the ideal of normality as representing a comfortable, hasslefree life with unproblematic identities. In addition, the ethno-sectarian divisions that they observe in workplaces and beyond go uneasily with the idealisation of the UK as a modern country characterised by good employment standards and open labour markets, as described in previous literature (e.g. Gałasińska and Kozłowska 2009). The next section discusses further areas where the discourse of normality may clash with the actual experience of life in this part of the UK.

\section{Constrained selves and a sense of suffocation and frustration.}

According to Evans, Taylor and Fraser (1996), everyday practices and assumptions are another sphere in which Local Structure of Feelings can be conveyed. Looking for these themes in narratives by migrant workers in Northern Ireland, one can observe a selfconstraint exercised on a daily basis in different aspects of their lives. One instance of such self-constraint is related to the expression of one's views or identities, and it can be illustrated with a quote from Hania:

If someone is called Kevin, $90 \%$ chances are that he will be Catholic. If someone is Ben, he will probably be a Protestant. Then you know what you can talk about with the first one and with the other. Even the conflict in Palestine now. This society is 
divided in a stupid way in that they hang up Israeli flags only because the Catholics identify with Palestine. But it's just in opposition to Catholics that they hang Israeli flags up (...). Recently there was a question about Scottish independence. In our office this topic comes up only when the only people left in the room were those of, let's say, the same political and religious identity. Otherwise these are the topics one does not talk about. See, if you brought up this topic in England where you have a multi-polar society, you can be open for discussion and you're not afraid to talk. But here this discussion also brings up the issue a range of other political views that you have.

Hania, 31 years old, NGO worker

According to Hania, one cannot express one's views freely but, rather, has to make them congruent with an existing set of political allegiances defined by sectarianism. As a result, a person must cautiously manage what is said to whom. Her reference to the Scottish independence referendum is interesting in the context of the larger research project which the present study is part of. This is because Polish interviewees in Scotland, who actually had a right to vote in this referendum, felt free to discuss it with their acquaintances. Moreover, when justifying their opinions they sometimes manifested an attitude that could be seen as rather nonchalant in Northern Ireland, where one's standpoint on this topic might virtually define the person's entire worldview and identity (e.g voting for fun or a thrill). This sense of constraint conveyed in the narratives of migrants in Northern Ireland also comes to the fore when compared with the accounts of a multicultural character of a host society that appeared repeatedly in interviews with migrants in Edinburgh, for example:

This society is multicultural and social frames are bent and have holes. By living here, you shake off all prescriptions and prohibitions like a dog that has just walked out of a river and shakes water off itself. Aneta, 34 years old, café worker, Edinburgh 
The second instance of migrants' practices that convey the ongoing selfconstraint that they exercise in Northern Ireland is that of refraining from entering certain neighbourhoods. This was already hinted at in the quotes discussed in the previous section, where the notions of red line or no-go districts appeared. In turn, the third instance of practices that convey a continual self-surveillance and constraint is subtler and more tacit. To be specific, it is seen indirectly in the way migrants talk and the words they use. For example, people interviewed in public places commonly lowered their voices when speaking the words 'Protestant' or 'Catholic', sometimes preceding them with a quick glance around the café or restaurant where the interview took place, as if to scan for any potential threat. Another technique was to refer to Catholics as 'those of our religion' and Protestants as 'those of the other religion' in order to avoid using the two words, which the quote from a thirty-five-year-old shop assistant named Roman illustrates: 'There were a few houses which belonged to strictly Pro... those of the other religion. I'm going to avoid certain words.'

As previously explained, Evans, Taylor and Fraser (1996) defined Local Structure of Feeling in terms of everyday practices and assumptions as well as the interpretations, sense and meanings of a place that they convey. The exercise of such caution and self-restraint in the way people speak is perhaps the best example of everyday practices and assumptions characterising migrants' lives in Northern Ireland. These practices convey a sense of a place as marked by feelings of insecurity and fear, and an interpretation of Northern Ireland as not fully normal.

Moreover, such constraints placed on an individual may also lead to a sense of suffocation and frustration with life in Northern Ireland. This can be sensed in, for example, the previous quote from Hania where she called the social reality of Northern Ireland 'stupid'. But it can best be illustrated by a quote from Kaja: 
What hurts me is that when there are some situations with regards to discrimination in general, no matter what the discussion will end up on the local conflict between the Catholics and Protestants. For them it's the most important problem and everything else is pushed aside.

Kaja, 28 years old, self-employed

In this comment, Kaja expresses frustration with something that, in the words of Garvey and Stewart $(2015,399)$, could be described as the drowning out of a diversity of experience, in particular the experience unique to migrants, by 'the noise of political and community discourses that have focused on the war between two dominant communities'. In such a discursive context, it can be hard for migrant workers to find space for themselves and their experience. This is indicated in the latter part of her narrative, which continues in the quote below, when Kaja talks about people wanting to take a breath and escape to another place. In addition, she (re)interprets the part of the UK that she came to not as a normal and modern place but, instead, as a parochial province:

\footnotetext{
After all, I think one can't hide that Belfast is a province ... and a lot of people run away from here. A lot of my friends moved out from here. Some people just want to take a breath and live somewhere else. I think that it's not a typical big city. It's not huge but, after all, it's the capital of this province. But what I wanted to say really is that usually big cities usually attract diversity, and that there's more tolerance in cities than outside them. But Belfast is quite different, specific. Kaja, 28 years old, self-employed
}

In the light of such severe constraints on individuals, can the longing for a normal life identified in previous literature on Polish migrants be satisfied in this part of the UK? The next section indicates that, indeed, it can. 


\section{7. 'The Irish keep it to themselves': sustaining the notion of a normal life and North-as-normal.}

Despite negative interpretations of Northern Ireland as directly and indirectly conveyed in previous quotes, as well as a sense of frustration, suffocation, uncertainty, and insecurity accompanying these interpretations, the discourse of normality similar to that identified in previous studies on Polish migrants in the UK prevailed in most narratives. When justifying their decisions to settle in Northern Ireland, interviewees emphasised the comfortable, hassle-free lives in which they could realise their material and nonmaterial aspirations:

This is my home. I have my flat here and my family. My son goes to the school here. I have a job here. I even have a British citizenship and local friends. Life goes on normally. Besides all those minuses that I told you about, there are many pluses. One can't demonise it. (...) There is a lot of good things and one should be happy with them. One of these things is a hassle-free life.

Roman, 35 years old, shop assistant

Such narratives are consistent with the sense of North-as-normal, conceptualised by Garvey and Stewart (2015) as a veil covering the tensions and reality of life in Northern Ireland, which they identified in their study of CEE migrant workers. In line with this observation, despite the experiences of divided workplaces and not infrequent exploitation and discrimination, migrants typically talked about working standards in very positive terms. Moreover, somewhat contradicting the picture that emerged from the discussion above, most interviewees, when directly asked about it, said that sectarianism did not affect or constrain them personally. Instead, the dominant opinion was that sectarianism was something that happened between people who were born or grew up in Northern Ireland without having any effect on migrants: 'But this conflict 
doesn't affect us. The Irish just keep it between themselves' (Wiktor, 31 years old, factory worker).

Despite the previously discussed constraints experienced by migrants, migrant workers seemed to feel that they could exercise a relatively high degree of choice and autonomy in their lives, especially when compared to what might be viable for Catholic people born here. For example, marriages between Protestants and Catholics are not particularly common in the North. Yet, migrant workers did not see such mixed relationships as problematic. This can be illustrated with the quote below in which Daria recollects how she was accepted by her boyfriend's parents despite being a Catholic.

I met my boyfriend who is a Protestant and obviously and I met his family. And to be honest when we started going out, you know, he had a problem. He said: 'I don't know what my parents are gonna think of you because you are Polish and you're a Catholic'. And he was quite concerned obviously. I sort of didn't see the problem. Like, you know, what is the problem? But then when they met me, they were like: 'God, you know, you're Polish. You're fine. You're not a local Catholic'.

Daria, 28 years old, self-employed

Moreover, contrary to previous literature on Polish migrants in Belfast, where it was argued that 'narratives of Belfast as a strictly divided city may be permeated with strong feelings of fear' and that 'this fear is particularly intensive when migrants walk through the Protestant parts of the city' (Kempny 2013, 440), several interviews in the present study indicated something completely opposite, namely, that Catholic parts of the city can be seen as more dangerous:

Grzegorz: It's my own theory but I think that there are many indicators that support it. In my opinion the republican side overslept its opportunity. They've never tried to bring us closer to them. In a sense 'OK, there's so many of you, come join us to 
strengthen our republican community'. Protestants, on the other hand, approached it in a very smart way. 'OK, you're Catholics but you are Catholics in Poland. So we won't identify you as our, local Catholics.' And it was super clever. Interviewer: So when it comes to the Catholic areas, it's more difficult there? Grzegorz: They don't trust anyone. There's a place which shows all these subtleties as if under a magnifier. It's a Catholic enclave, very small, and it's called Shore Strand. It's surrounded by the Protestant East. Here whoever is from the outside gets beaten. It doesn't matter whether you're a Polish pizza delivery worker or a hard-core Protestant.

Grzegorz, 39 years old, professional services worker

In line with this observation, living in Protestant neighbourhoods was not uncommon among the interviewees. Indeed, previous data on Belfast suggest that Polish migrants live predominantly in Protestant neighbourhoods (Wardach 2016). Going beyond this, it is interesting to look at practices of migrants who live in these neighbourhoods as they illustrate the flexibility with which they navigated through the ethno-sectarian identities of the North. The case of Karolina, a thirty-two-year-old café worker, who described the Protestant neighbourhood where she lived as the 'blackest hole in whole Ireland', is particularly illustrative: 'It's a beautiful house but, you see, I think that this neighbourhood is the blackest hole in whole Ireland. (...) The owners of this house are also staunch Protestants'. However, Karolina said that she felt completely safe and welcomed by this community, despite sending her children to a Catholic school, working in a predominantly Catholic workplace and having tried to obtain Irish rather than UK citizenship because of her emotional attachment to the former country. Just as for other interviewees, for Karolina sectarianism was something that happened predominantly among the people who were born or grew up in Northern Ireland and did not involve more recent arrivals. Grzegorz, who has already been quoted, also lived in the Protestant neighbourhood of east Belfast while sending his child to a Catholic school but, at the same time, pledged allegiance to the UK state and England: 
After all, it's the capital city. Yes, a capital of Northern Ireland, but still a capital. And it's also part of the UK. English currency, English law. I'm very happy that, after all, it's part of the UK and not Ireland.

Grzegorz, 39 years old, professional services worker

Similarly, Roman professed greater sympathy with the English as well as a Protestant identity even though he lived in a Catholic district of Belfast: 'I prefer local English, Protestant people because I know what to expect from them. They have been my acquaintances and employers for four years now and I prefer working with them'. Although the actual source of his sympathy remains unclear, his statement underscores the argument made above about the extent of flexibility with which migrants appear to treat ethno-sectarian boundaries. This flexibility allows them to live the normal lives with unproblematic identities that they longed for: to buy houses, start families, and act as consumers and relatively unconstrained entrepreneurs of selves. In this way, the discourse of normality can be sustained. However, as the next section suggests, there is a cost to this normality.

\section{Discussion: normality through exclusion?}

On the one hand, it is certainly a good thing that migrant workers can lead lives that, at least on the surface, are relatively little affected by sectarianism. On the other hand, there is a downside to their apparently normal lives in that they may remain an excluded social group in the society that has become their home. This exclusion can be best illustrated by unpacking the following quote:

When talking about inclusion, one should distinguish between people from the outside - I mean migrants - and the local ones. When it comes to immigrants, I don't think there's a problem and, if there is, it's marginal. But when it comes to locals, then one cannot say that one is an Irish from the North with no colour. After all it has to be orange or green. (...) I will never be an Irish Catholic, nor Irish 
Protestant. Nor will I be an Irish or Northern Irish. I will always be a Polish person who lives here.

Grzegorz, 39 years old, professional services worker

This quote shows very explicitly how sectarian identities may generate a sense of exclusion among migrants from Poland. This contrasts with the potential effect of civic nationalist discourse in Scotland that may allow migrants to combine Polish and Scottish identities which can be illustrated with a quote by Janusz, a 33 year old professional services worker, who said: 'I like Scottish patriotism which is that you're a Pole wearing a kilt - awesome!'.

Moreover, by positioning themselves within either designation, Polish migrants in Northern Ireland would potentially risk their comfortable, hassle-free, normal lives by being dragged into ethno-sectarian competition and animosity. In other words, they can sustain their normal lives as long as they sustain the privatised mode of living that is centred on their homes, families, private consumption, and self-enterprising. This places migrant workers in a weak position to challenge the subordination that Garvey and Stewart (2015) talk about. According to these authors, the political (and social) settlement at the end of the Troubles created a new form of social subordination by 'allowing the main protagonists to the older conflict time to divide the spoils' and leaving the migrant workers outside (Garvey and Stewart 2015, 402).

This exclusion applies also in the sphere of employment, which can be illustrated by the experience of Marek. Even though, immediately after his arrival in Northern Ireland, he easily found a job in a factory that did not employ any Irish Catholics, his experiences in this workplace indicate exclusion rather than inclusion (or at least unequal inclusion):

They treated us as a cheap workforce. Really. I noticed it later. They put an extreme pressure on us but not on the Irish workers. For example, the boss tells you 
to go faster, faster and faster and then he goes and talks behind your back with an Irish workers and they both laugh at you. You understand? That you have to work your ass off while the Irish workers just hang around and pretend that they are working. And we, the Poles, were working like ants.

Marek, 35 years old, factory worker

Knowing that the boss and local workers having a friendly chat behind migrants' backs were of the same ethno-sectarian denomination, we can read the quote above as an illustration of the paternalistic employment relations between management and workers that can be found in some workplaces in Northern Ireland, and from which migrant workers are excluded. As shown in Garvey and Stewart's (2015) study, challenging this exclusion can lead to serious danger for workers, including sectarian violence from the paramilitaries. Of course, not all workplaces are characterised by such anachronistic employment relations. Therefore, the extent to which workplace exclusion or marginalisation affects a person and to which it can be challenged will ultimately depend on migrants' position in the labour market. As Murtagh and Shirlow $(2006,139)$ put it: "The worst thing that could happen in the offices is that someone would throw a bagel at you. On the shop floor, you could get a spanner in the teeth'.

Furthermore, individual circumstances can be improved if a person becomes integrated into one of the dominant communities. For example, Marek, who initially faced discrimination in his workplace, as indicated in the previous quote, became integrated into the paternalistic employment relations in another workplace after marrying a Protestant woman who was a relative of its owner. However, even though individuals can change their position within the host society, to the extent that the entire political system of Northern Ireland is built on ethno-sectarian divisions, migrants as a social group remain excluded. 


\section{Conclusions}

Previous literature on Polish migration to the UK spoke of the discourse of normality as the new grand narrative in people's justifications for working and living abroad. The discourse of normality refers to the longing for comfortable, unproblematic lives and identities free from material deprivation. Normality thus understood is subjectively associated with the UK. However, after problematising the idealised and homogenised image of the UK conveyed in this discourse, the present article posed the question: what happens to the discourse of normality in parts of Britain where it cannot be easily sustained? To explore this question, migration to Northern Ireland - a post-conflict society still ridden by sectarian divisions and violence that shape labour market, workplace, and community relations - was chosen as an arguably extreme case.

The empirical data analysis showed that the discourse of normality sits uneasily with the Structure of Feeling that the migrants interviewed in this study developed in relation to Northern Ireland. First of all, the idealisation of the UK as a wealthy, modern, open country where unproblematic identities can be forged, ran counter to migrants' narratives of segregated workplaces, communities, and other representations of Northern Ireland as a parochial rather than normal place. Secondly, the notion of normal, unproblematic, comfortable lives in the UK is put under strain by the feelings of insecurity, uncertainty, fear, frustration and suffocation conveyed in migrants' narratives and, indirectly, through their everyday practices.

However, it was also shown that, parallel to such experiences and interpretations of Northern Ireland, migrants sustained the discourse of normality and conveyed a sense that normal lives are achievable despite sectarianism. They appeared to treat the two dominant identities of Irish nationalism and Protestant loyalism with a degree of flexibility, 'shopping' between the two and picking whatever best suited them: e.g. 
Catholic school for a child, Protestant neighbourhood to live in, Irish citizenship, and so on.

In accounting for this apparent contradiction within the data, it was suggested that normality is maintained through the exclusion of migrant workers as a social group. Although on the individual level Polish migrants can make a 'normal' living in Northern Ireland, become integrated into families and workplaces in this country, and live apparently unproblematic lives as consumers and self-entrepreneurs, they remain excluded as a group by being confined largely to their private lives. This is the price of normality that Polish migrants in Northern Ireland pay. Moreover, the price is arguably higher for those at the lower end of the labour market.

This conclusion somewhat problematises the notion of normality. In addition, it indicates that, although the experience of migration to Northern Ireland may not seem straightforwardly different from the experience of migration to other parts of the UK, in that a sense of and discourse of normality is sustained, there are certain subtleties in this experience that the concept of Local Structure of Feeling seems well suited to explain. Therefore, it is hoped that the present article, apart from contributing to the literature on Polish migration to the UK, will encourage scholars of migration to envision the possibility of researching the subject in different terms, by offering a conceptual tool that allows better theorisation of the role of a place of destination in shaping migration experience.

\section{Disclosure Statement}

No potential conflict of interest was reported by the author.

\section{References:}


Anderson, Bridget. 2013. Us and Them? The Dangerous Politics of Immigration Control. Oxford: Oxford Scholarship Online.

Blumer, Herbert. 1969. Symbolic interactionism: perspective and method. Englewood Cliffs: Prentice-Hall.

Department of Employment and Learning. 2009. Labour Market and Skills Impacts of Migrant Workers in NI. Lisburn: Oxford Economics with McClure Watters and Perspective Insight Market Research.

Drinkwater, Stephen and Michal P. Garapich. 2015. "Migration Strategies of Polish Migrants: Do They Have Any at All?" Journal of Ethnic and Migration Studies 41(12), 1909 - 1931. doi: 10.1080/1369183X.2015.1027180.

Düvell, Franck and Vogel, Dita. 2006. "Polish Migrants: Tensions between Sociological Typologies and State Categories." In Contemporary Polish Migration in Europe. Complex Patterns of Movement and Settlement, edited by Anna Triandafyllidou, 267 - 289. New York: Edwin Mellen Press.

Eade, John, Stephen Drinkwater, and Michal P. Garapich. 2006. "Class and Ethnicity: Polish Migrant Workers in London." Swindon: Economic and Social Research Council, End of Award Report No. RES-000-22-1294.

Engbersen, Godfried, Arjen Leerkes, Izabela Grabowska-Lusińska, Erik Snel,and Jack Burgers. 2013. "On the Differential Attachments of Migrants from Central and Eastern Europe: A Typology of Labour Migration.” Journal of Ethnic and Migration Studies 39 (6), 959 - 981. Doi: 10.1080/1369183X.2013.765663.

Evans, Karen, Ian Taylor, and Penny Fraser. 1996. A Tale of Two Cities: Global Change, Local Feeling and Everyday Life in the North of England. A Study in Manchester and Sheffield. London and New York: Routledge.

Gałasińska, Aleksandra and Olga Kozłowska. 2009. "Discourses of a 'Normal Life' Among Post-Accession Migrants from Poland to Britain.” In Polish Migration to the UK in the 'New' European Union, edited by Kathy Burrell, $87-106$. New York: Routledge.

Garvey, Brian and Paul Stewart. 2015. "Migrant Workers and the North of Ireland: Between Neoliberalism and Sectarianism." Work, Employment and Society 29(3): 1-17. doi: 10.1177/950017014556800.

Glaser, Barney. 1978. Theoretical sensitivity. Mill Valley: The Sociology Press. Grabowska-Lusińska, Izabela and Marek Okólski. 2009. Emigracja Ostatnia? Warsaw: Wydawnictwo Naukowe Scholar. 
Kazimierska, Kaja, Andrzej Piotrowski, and Katarzyna Waniek. 2011. Biographical Consequences of Working Aborad in the Context of European Mental Space Construction. Sociological Review, 60(1): 139 - 158. p-ISSN: 0033-2356.

Kelly, Brian. 2012. "Neoliberal Belfast: Disaster Ahead?” Irish Marxist Review 1(2): 44-59.

Kennedy, Michael D. 1994. "An Introduction to Eastern European Ideology and Identity in Transformation." Envisioning Eastern Europe: Postcommunist Cultural Studies, edited by In Michael D, 1 - 28. Kennedy. Weinheim: Deutscher Studien Verlag.

Kempny, Marta. 2013. “Tales from the Borderlands: Polish Migrants' Representations of the Northern Irish Conflict in Belfast." Space and Culture 16(4): 435 - 446. doi: $10.1177 / 1206331212452818$.

McCollum, David and Allan Findlay. 2011. “'Flexible’ Workers for 'Flexible’ Jobs? The Labour Market Function of A8 Migrant Labour in the UK." Work, Employment and society 29(3): 427 - 433. doi: 10.1177/0950017014568137.

McGhee, Derek, Sue Heath, and Paulina Trevena. 2012. "Dignity, Happiness and Being Able to Live a 'Normal Life' in the UK - an Examination of Post-Accession Polish Migrants' Transnational Autobiographical Fields.” Social Identities: Journal of the Study of Race, Nation and Culture 18(6): 1 - 17. doi: 10.1080/13504630.2012.709002.

Murtagh, Brendan and Peter Shirlow. 2012. "Devolution and the Politics of Development in Northern Ireland.” Environment and Planning C: Government and Policy 30(1): 46 - 61. doi: 10.1068/c10216r.

Murtagh, Brendan and Peter Shirlow (2006) Belfast: Segregation, Violence and the City. London: Pluto Press.

Rabikowska, Marta. 2010. "Negotiating Normality and Identity among Migrants from Eastern Europe to the United Kingdom after 2004.” Social Identities 16(3), 285 - 296. doi: 10.1080/13504630.2010.482391.

Rausing, Sigrid. 2002. "Re-Constructing the 'Normal': Identity and Consumption of Western Goods.” In Markets and Moralities: Ethnographies of Postcolonialism, edited by Ruth Mandel and Caroline Humphrey, 127 - 142. Oxford: Berg.

Rijswijk, Wendy, Nick Hopkins, and Hannah Johnston. 2009. "The Role of Social Categorisation and Identity Threat in the Perception of Migrants." Community and Applied Social Psychology 19(6): 515 - 520. doi: 0.1002/casp.1011. 
Sommers, Jeffrey and Charles Woolfson. 2008. "Trajectories of Entropy and 'the Labour Question': The Political Economy of Post-communist Migration in the New Europe." Journal of Contemporary Central and Eastern Europe 16(1): 55 - 71. doi: 10.1080/09651560801987187.

Wardach, Iwona. 2016. "Polish Residents in Belfast: Issues of Discrimination, safety and Integration.” Belfast Interface Project. Accessed 07 July 2016. http://www.belfastinterfaceproject.org/publication/polish-residents-belfast.

Williams, Raymond. 1961. The Long Revolution. London: Chatto and Windus. 